\title{
IAMJ
}

INTERNATIONAL

AYURVEDIC

MEDICAL JOURNAL

Review Article

ISSN: 23205091

Impact Factor: 5.344

\section{HEALING POWER OF AYURVEDA FOR ADDICTION}

\author{
Pathak Reetika $^{* 1}$, Inchulkar S. R. ${ }^{2}$, Bhagat Sangeeta ${ }^{3}$ \\ ${ }^{* 1}$ MD Scholar, ${ }^{2}$ Professor \& HOD, ${ }^{3}$ Lecturer, \\ Department. of Agad Tantra Evam Vidhi Ayurved, Shri N.P.A Govt. Ayurvedic College Raipur, Chhattisgarh, \\ India
}

Corresponding Author: pathakreetika922@gmail.com

https://doi.org/10.46607/iamj2008112020

(Published online: November 2020)

Open Access

(C) International Ayurvedic Medical Journal, India 2020

Article Received: 20/10/2020 - Peer Reviewed: 06/11/2020 - Accepted for Publication: 10/11/2020

\section{Check for updates}

\section{ABSTRACT}

Addiction is habitual psychological or physiological dependence on a substance or practice that is beyond voluntary control. It is a chronic brain disease that causes compulsive substance use despite harmful consequences. Addiction causes widespread harmful effect to human being along with its social consequences. The term addiction does not only refer to dependence on substance such as heroin or alcohol. A person who cannot stop taking a particular drug or chemical has substance dependence. In Ayurveda every human being is considered a combination of both mind and body. The perfect balance of mind, body and soul is considered ideal health in Ayurveda and is the result of a pure body and selfless mind. There are specific mental treatments in Ayurveda to cure physical problems as well as mental disorders. The mental attitude of a person plays an important role in the caring process. Even modern medical science admits that there is a direct co-relation between a healthy mind and healthy body. Ayurveda helps in an addict's long-term recovery by changing their lifestyle rather than simply giving them a pill to swallow. Ayurvedic therapy is generally accomplished through a careful diet, herbal medicines, exercise, massage therapy, personal counseling and forms of Yoga. Present article is aimed to explore all the possible treatment modalities from the treasure of Ayurved texts which may be used for de-addiction

Keywords: Ayurveda, Addiction, Health, Counseling, Yoga, 


\section{INTRODUCTION}

Addiction is a psychological and physical inability to stop consuming a chemical drug activity or substance even though it is causing psychological and physical harm. Addictive habits have been a part of society for as long as plants have been growing on the planet. We all know the ugly side of addiction that some people fall into substance like drugs, alcohol, tobacco etc. are not only an individual's problem but also affects his/her family, friends, workplace and society as a whole. The addicted individual experiences, financial, physical, psychological, emotional, family and social problems. All of this suffering creates a spiritual crisis of sorts. Ayurveda can address these issues. There are specific mental treatments in Ayurveda to cure physical problems as well as mental disorders. Ayurveda can offer a number of treatments that may be of value for people recovering from an addiction.

\section{Aim and Objectives -}

1. To evaluate, elaborate and discussed the addiction as per Ayurveda.

2. To evaluate, elaborate and discussed the solution of addiction as per Ayurveda.

\section{Methodology -}

- For this review article different Ayurvedic textbooks, classical Ayurveda and modern books, reference books, magazines, journals were searched and analyzed.

\section{Diagnosis of addiction in Ayurvedic way-}

The diagnosis in Ayurveda comprises of a detailed understanding of a person's characteristics, habits, sleep patterns, hereditary traits body type etc. as a first step. Followed by that will be an understanding of the state of the 'Tridoshas' within an individual Vatta, Pitta and Kapha. Ayurveda believes that the problems in a human body are caused due to the misbalance among these doshas. Some of the other diagnosis techniques that are frequently used by Ayurvedic experts are diagnosis of tongue, diagnosis of nails, eye and diagnosis of the pulse. These diagnoses provide vital clues about the nature and tendencies of the individual.
De-addiction treatment in Ayurvedic way - Deaddiction treatment comprises of the following way in Ayurveda:-

\section{- Purification Therapies -}

These are also known as Panchakarma therapies which target at uprooting the toxins present in the patient's body. These are quite potent therapies and are generally done under the supervision of an Ayurvedic expert. Virechana is the therapy which comprises of taking a mixture of herbal medicinal plants or their parts. This therapy eliminates the toxic substance from the body via the anal route. Herbs like Ginger, Cardamom, Cinnamon and Embelia etc. are used for this purpose. Another popular cleansing therapy used is Vamana which can be called a therapy for vomiting. This method uses the upper track leading to the mouth, to cleanse the toxins caused due to indigestion of food. Ayurvedic Panchakarma helps addict to recover from it, by cleaning the body's deep tissues of toxins, opening the subtle channels, bringing life changing energy therapy increasing vitality inner peace, confidence and well-being. An expert Ayurveda physician can help to overcome this dreadful condition in a different way ${ }^{[1]}$.

\section{- Rasayana therapies -}

Another highly effective treatment in Ayurveda for deaddiction is the Rasayana therapies. The Rasayana therapy primarily works on the basis of transmutation and conservation of our energy to improve both our mental as well as physical characteristics so as to improve our body's natural metabolic process while at the same time enhancing the functioning of the brain and the immune system. These therapies generally follow the Panchakarma treatments which purify the body. This set of procedures further nourishes and strengthens the body after Panchakarma, for addiction related problems, Rasayana treatment include dietary changes and consuming oral herbal medicines. ${ }^{[2]}$

\section{- Oral medication -}

A range of herbal medicines and combinations are used in the treatment of addictive problems, which are ment to be administered orally. Jatamansi (Nardostachys jatamansi) and Ashwagandha 
(Withania somnifera) are two herbs that are used in combination to heal lungs damaged from smoking, they actually help in removing smoke in the lung and healing the internal tissues. Congestion reliving herbs like Ginger (Zingiber officinale) and Pippali (Piper longum) mixed with honey and lemon are also prescribed for the addiction affected individuals. Kapikacchu (Mucuna pruriens) can also be very helpful by revitalizing and balancing the mind. The Brahmi (Bacopa monnieri) and Mandookparni (Centella asiatica) herbs are used to cleanse hallucinogenic drugs from the liver and brain. Consuming the Ashwagandha (Withania somnifera) herb helps to rebuild the nervous system. Shatavari (Asparagus racemosus) helps to restore emotion sensitivity and balance to an addict. ${ }^{[3]}$

\section{- Massage therapy -}

Abhyanga is a specialized form of massage therapy used in Ayurveda, for 15 to 30 minutes therapists' massage warm, herb-infused, oils into those undergoing treatment. This wonderfully relaxing and energizing massage relieves stress anxiety and feelings of being overwhelmed with their addiction. ${ }^{[4]}$

\section{- Yoga and Meditation -}

Yoga is the Sanskrit word for union. Yoga is a physical and spiritual union between the mind and the body. Yoga is a practice that combines physical activity and physical postures, breathing awareness mind fullness and meditation. The regular practice of Yoga postures can improve health and help people deal better with stress. According to Ayurveda medicine, it will also restore energetic balance in the body and provide deep purification following the cessation of alcohol and drug abuse. The system has also been recommended as a behavioral therapy for smoking cessation and substance abuse (including alcohol abuse). ${ }^{[5]}$ Meditation is a wonderful tool for people recovering from an addiction. It not only helps them better deal with stress, but it can also increase their ability to manage the stressors that occur in their life. ${ }^{[6]}$

\section{- Dietary changes -}

The Ayurvedic type of diet provides the patient with adequate nutrition and plenty of rest to the affected organs, so diet regulation is also helpful in such cases. Diet rich in proteins and carbohydrates and low fat's is recommended. The patient should eat fiber rich food and plenty of raw vegetables. Intake of coffee and tea etc. should be reduced and alcohol should not be touched. Most addicts suffer from nutritional deficiencies so following an Ayurvedic diet may help with a qualified dietician, this is particularly important in the early recovery. ${ }^{[7]}$

\section{- Psychological counseling -}

Psychological counseling has very important role in de-addiction. It is also mentioned in Ayurvedic Samhita which aware the patient from ill effects of addiction and give will power to come out from addiction. It is needed to correct awareness about the ill-effects of addiction. A warm friendly and sympathetic relationship between the therapist and the patient is the basis of any psychotherapeutic procedure. ${ }^{[8]}$

\section{DISCUSSION}

Addiction is the major problem in the world including India. As the number of drug addicts is fast rising in the country, it is important for their families and general practitioners to understand the psychosomatic problems caused by drug abused. Many different types of drugs can be addicted not only illegal drugs such as heroin, cannabis, cocaine or ecstasy, but also prescriptions drugs such as tranquilizers, analgesic etc. Addiction is a state of physical or psychological dependence on a substance. Acharya Charak stated the concept of Oak-Satmya ${ }^{[9]}$ on which Acharya Chakrapani has given the commentary that Apathy (unwholesome) substance whatever it may be harmful or less harmful may become Satmya (homologous) due to continuous prolonged utilization. Hence, we can conclude that an addiction is a form of Satmya through the prolonged adverse effect of substance depends upon the nature, property, dose of substance duration and mode of utilization. In Panchakarma therapy Abhyang, Virechana and Vamana is helpful to normalize the vitiated Vata and reduces anxiety, stress and insomnia. Psychological counseling has very important role in de-addiction. It is also mentioned in 
Ayurvedic Samhitas which aware the patient from ill effects of drug addiction and give will power to come out from drug addiction. As the psychological manifestation of drug withdrawal hence Abhyanga, Meditation, Rasayana therapy, Psychological counseling should be extended for addiction patients. $^{[10]}$

\section{CONCLUSION -}

Ayurveda does not force someone to stop the addictive behavior but encourage to replace it with another more constructive habit. The uniqueness of Ayurveda is that it not only attacks the roots of an addiction, but also helps to remove the toxins of the body. The general belief is drug addiction or intoxication of any kind is a social as well as psychological problem, which needs a holistic approach of treatment keeping in mind the affected person's socio-economic condition and atmosphere in mind. Ayurveda does just that and adopts a systematic approach in treatment of addiction cases. Those who are already established in recovery from addiction may find that Ayurveda helps them to maintain good physical, mental and spiritual health.

\section{REFERENCES}

1. Dr. Brahmanand Tripathi, hindi commentary, CharakSamhita, Sutrasthan, 16/20, Reprint edition 2006, Chaukhamba Surbharti Prakasan Varanasi, Page; 323

2. Dr. Brahmanand Tripathi, hindi commentary, CharakSamhita, Chikitsasthan, 1/1/8, Reprint edition 2007, Chaukhamba Surbharti Prakasan Varanasi, Page; 05

3. Dr. Brahmanand Tripathi, hindi commentary, CharakSamhita, Sutrasthan, 11/54, Reprint edition 2006, Chaukhamba Surbharti Prakasan Varanasi, Page; 248

4. Dr. Anil K. Mehta and Dr. Raghunandan Sharma, Ayurvedic Physiotherapy and Yoga, Chapter-04, First Edition 2010, Chaukhamba Sanskrit Pratishthan Delhi, Page; 62-63

5. Dr. Anil K. Mehta and Dr. Raghunandan Sharma, Ayurvedic Physiotherapy and Yoga, Chapter-15, First Edition 2010, Chaukhamba Sanskrit Pratishthan Delhi, Page; 366

6. Dr. Vimala Karnatak, Himdi commentary, Patanjal yog-sutra, Maharshi Patanjali, 2/29, First edition 1996, Krishnadas Academy Varanasi, Page; 186
7. Dr. Brahmanand Tripathi, hindi commentary, CharakSamhita, Sutrasthan, 28/45, Reprint edition 2006, Chaukhamba Surbharti Prakasan Varanasi, Page; 553

8. Dr. Brahmanand Tripathi, hindi commentary, CharakSamhita, Sutrasthan, 11/54, Reprint edition 2006, Chaukhamba Surbharti Prakasan Varanasi, Page; 248

9. Chakrapanidatta Ayurved-Deepika teeka, CharakSamhita, Sutrasthan, 5/103, Reprint edition 2006, Chaukhamba Surbharti Prakasan Varanasi, Page; 161

10. Dr. Brahmanand Tripathi, Hindi commentary, Astang Hrdayam, Sutrasthan, 4/36, Reprint edition 2012, Chaukhamba Sanskrit Pratishthan Delhi, Page; 62

\section{Source of Support: Nil \\ Conflict of Interest: None Declared}

How to cite this URL: Pathak Reetika et al: Healing Power Of Ayurveda For Addiction. International Ayurvedic Medical Journal \{online\} 2020 \{cited November, 2020\} Available from:

http://www.iamj.in/posts/images/upload/5096 5099.pdf 